\title{
Recombinant hirudin suppresses the viability, adhesion, migration and invasion of Hep-2 human laryngeal cancer cells
}

\author{
QIAN LU ${ }^{1,2}$, MEI LV ${ }^{1}$, ERDONG XU ${ }^{1}$, FANGYU SHAO ${ }^{1}$, YA FENG $^{1}$, JINGRU YANG $^{1}$ and LIN SHI ${ }^{1}$ \\ ${ }^{1}$ Department of Otorhinolaryngology and Head and Neck Surgery, The First Affiliated Hospital of Dalian Medical University, \\ Dalian, Liaoning 116011; ${ }^{2}$ College of Basic Medicine, Jilin Medical College, Jilin, Jinlin 132013, P.R. China
}

Received September 13, 2014; Accepted December 9, 2014

DOI: 10.3892/or.2015.3717

\begin{abstract}
Recombinant hirudin ( $\mathrm{rH})$ is a highly potent and specific inhibitor of thrombin, and has been shown to inhibit the growth and metastasis of several types of cancers in experimental tumor models. The objective of this study was to evaluate the antitumor effects and explore the underlying mechanisms of $\mathrm{rH}$ in Hep-2 human laryngeal carcinoma (LC) cells. Hep-2 cells were treated with various concentrations of $\mathrm{rH}$ for $24 \mathrm{~h}$. The cell viability was evaluated by a water-soluble tetrazolium salt (WST) assay. The adhesion ability of the cells was evaluated by cell adhesion to fibronectin. Cell migration and invasion were measured with the Boyden chamber assay. Cell apoptosis was detected by Hoechst 33324 fluorescence staining. A chicken chorioallantoic membrane (CAM) assay was used to assess the effects of $\mathrm{rH}$ on angiogenesis in vivo. Western blotting was used to detect the expression levels of vascular endothelial growth factor receptor (VEGF-R), focal adhesion kinase (FAK), Bcl-2-associated agonist of cell death $(\mathrm{Bad})$ and $\mathrm{B}$-cell CLL/lymphoma $2(\mathrm{Bcl}-2)$ proteins. $\mathrm{rH}$ significantly inhibited the cell viability and induced apoptosis in LC Hep-2 cells in a dose-dependent manner, as compared with phosphate-buffered saline (PBS) as control. These results were accompanied by a decrease in the anti-apoptotic protein $\mathrm{Bcl}-2$ and an increase in the pro-apoptotic protein Bad. Moreover, $\mathrm{rH}$ dose-dependently inhibited the adhesion, migration and invasion of the Hep-2 cells, compared to the vehicle PBS. In addition, $\mathrm{rH}$ robustly suppressed angiogenesis in the CAM assay. Importantly, the expression of adhesion
\end{abstract}

Correspondence to: Dr Mei Lv or Dr Erdong Xu, Department of Otorhinolaryngology and Head and Neck Surgery, The First Affiliated Hospital of Dalian Medical University, Dalian, Liaoning 116011, P.R. China

E-mail:1v_mei@163.com

E-mail: benxierdong@163.com

Abbreviations: LC, laryngeal carcinoma; $\mathrm{rH}$, recombinant hirudin; DOX, doxorubicin hydrochloride; Bcl-2, B-cell CLL/lymphoma 2; Bad, Bcl-2-associated agonist of cell death; VEGF-R, vascular endothelial growth factor receptor; FAK, focal adhesion kinase; CAM assay, chick chorioallantoic membrane assay

Key words: recombinant hirudin, Hep-2 cells, antitumor, apoptosis and angiogenesis-associated proteins FAK and VEGF-R was significantly downregulated by $\mathrm{rH}$ in a dose-dependent manner. The present findings demonstrate that $\mathrm{rH}$ exerts antitumor effects in Hep-2 human laryngeal cancer cells via multiple mechanisms and suggests that targeting thrombin by $\mathrm{rH}$ is a potential strategy for the treatment of LC.

\section{Introduction}

Laryngeal carcinoma (LC) is a common head and neck malignancy and accounts for $\sim 2.4 \%$ of newly diagnosed malignancies worldwide every year $(1,2)$. Surgery, chemotherapy and radiation therapy are the current treatment modules for laryngeal cancer (3-5). Although early-stage laryngeal cancer can be effectively treated with surgery or radiotherapy, the 5-year survival rate of patients with advanced LC is still below $60 \%$ even after systematic surgery and post-surgical adjuvant radiotherapy or chemotherapy (6). In addition, surgery may result in complete or partial loss of swallowing and vocal functions. Many patients have to maintain a tracheal cannula on a long-term basis due to laryngeal stenosis after surgery, which markedly impairs their quality of life $(6,7)$. Therefore, there is urgent need to develop novel approaches and strategies for the treatment of these advanced LC patients.

The development and progression of cancer are closely associated with thrombosis (8). Thrombin, the key terminal enzyme of coagulation, enhances angiogenesis, stimulates the adhesion of tumor cells to platelet and endothelium, and promotes the growth and metastasis of tumor cells (9). Previous in vitro studies have shown that exogenous thrombin $(1 \mathrm{U} / \mathrm{ml})$ acting through its protease-activated receptor (PAR)-1 is capable of enhancing tumor adhesion to platelets, endothelial cells, fibronectin and von Willebrand factor (10). Moreover, exogenous thrombin was shown to promote tumor growth as well as metastasis in experimental animals (11). In addition, in a chorioallantoic membrane (CAM) model, exogenous thrombin was demonstrated to induce angiogenesis (12). These data from in vitro and in vivo studies suggest that thrombin is a potential target for the development of molecular-targeted cancer therapies.

The anticoagulant recombinant hirudin $(\mathrm{rH})$ is a highly potent and specific inhibitor of thrombin, and has demonstrated antitumor effects in different types of tumors including melanoma, lung and prostate cancer (9). In a transgenic 
TRAMP mouse model of prostate cancer, inhibition of endogenous thrombin by hirudin retarded the growth of spontaneous tumors (9). Administration of hirudin at the early stage after tumor cell inoculation in experimental animals led to apparent central necrosis of the tumor nodule and inhibition of spontaneous metastases from the subcutaneously implanted tumors, accompanied by the reduced number of tumor nodules in the lungs (11). Moreover, administration of $\mathrm{rH}$ followed by stealthy liposomal vinblastine resulted in enhanced inhibition of the growth and metastasis of melanoma in vivo (10). Thus, targeting thrombin by $\mathrm{rH}$ is a promising strategy for the development of anticancer therapeutic modalities, particularly for those tumor cells with PAR-1 on the cell surface. However, whether rH exerts antitumor effects on LCs has not yet been investigated.

In the present study, we evaluated the antitumor effects of $\mathrm{rH}$ and explored the underlying mechanisms in LC cells. We treated Hep-2 LC cells with various dosages of $\mathrm{rH}$ and analyzed cell viability, adhesion, migration and invasion. We additionally assessed angiogenesis and apoptosis, and determined the expression levels of vascular endothelial growth factor receptor (VEGF-R), focal adhesion kinase (FAK), B-cell CLL/lymphoma 2 (Bcl-2)-associated agonist of cell death $(\mathrm{Bad})$ and $\mathrm{Bcl}-2$ following treatment of Hep-2 cells with $\mathrm{rH}$.

\section{Materials and methods}

Cell culture and treatment. Hep-2 human laryngeal cancer cells were obtained from Beinglay Biotech (Wuhan, China) and cultured at $37^{\circ} \mathrm{C}$ in a $5 \% \mathrm{CO}_{2}$ atmosphere in RPMI-1640 medium (Gibco, Grand Island, NY, USA) containing 10\% fetal bovine serum (FBS) (HyClone, Logan, UT, USA), and antibiotics (100 IU/ml penicillin and $100 \mathrm{IU} / \mathrm{ml}$ streptomycin). rH was purchased from Combination Botai Biotechnology (Dalian, China) and used at final concentrations of $0.5,1$, $2 \mathrm{mg} / \mathrm{ml}$ or $25,50,100 \mu \mathrm{g} / \mathrm{ml}$ in the experiments. The drugs were prepared in RPMI-1640 medium before addition to the cell cultures. Cells treated with phosphate-buffered saline (PBS) were used as the negative controls, and cells treated with doxorubicin hydrochloride (DOX) $(4 \mu \mathrm{g} / \mathrm{ml})$ as the positive controls.

Cell proliferation assay. Hep-2 cells were seeded in 96-well plates at a density of $10^{4}$ cells/well in RPMI-1640 containing $10 \% \mathrm{FBS}$ for $24 \mathrm{~h}$ and then treated with various concentrations of $\mathrm{rH}(0.5,1$ or $2 \mathrm{mg} / \mathrm{ml})$ or DOX $(4 \mu \mathrm{g} / \mathrm{ml})$. Following treatment for $24 \mathrm{~h}, 10 \mu \mathrm{l} /$ well of water-soluble tetrazolium salt (WST) (Beyotime, Beijing, China) was added, and the plates were incubated for an additional $4 \mathrm{~h}$. The spectrometric absorbance at a wavelength of $570 \mathrm{~nm}$ was measured on a microplate reader. This experiment was repeated in triplicate.

Cell adhesion to fibronectin. Fibronectin (BD Biosciences, San Jose, CA, USA) was diluted to a final concentration of $100 \mu \mathrm{g} / \mathrm{ml}$ in PBS and $40 \mu \mathrm{l}$ was added to each well of 96-well plates at $4^{\circ} \mathrm{C}$ overnight. Hep-2 cells were pretreated with various concentrations of $\mathrm{rH}(25,50$ or $100 \mu \mathrm{g} / \mathrm{ml})$ or DOX $(4 \mu \mathrm{g} / \mathrm{ml})$ for $0.5 \mathrm{~h}$. After treatment, $1 \times 10^{5}$ cells were added to each well of 96-well plates coated with fibronectin and incubated for $2 \mathrm{~h}$.
The cells that did not adhere to the fibronectin were removed. The bound cells were fixed with $4 \%$ (w/v) paraformaldehyde and stained with crystal violet, followed by gentle rinsing with PBS and drying. Afterwards, $1 \%$ SDS was added, followed by mixing. Spectrometric absorbance at a wavelength of $540 \mathrm{~nm}$ was measured on a microplate reader. This experiment was repeated in triplicate.

Cell migration and invasion assay. A Transwell assay was performed using polycarbonate Transwell filters (Corning Costar, Cambridge, MA, USA). Briefly, cells were suspended in culture medium containing various concentrations of $\mathrm{rH}(25,50 \mathrm{or} 100 \mu \mathrm{g} / \mathrm{ml})$ or DOX $(4 \mu \mathrm{g} / \mathrm{ml})$ and plated to the upper chamber with the bottom filled with culture medium containing basic fibroblast growth factor (bFGF) (Roche, Basel, Switzerland) (3 ng/ml). After incubation for $24 \mathrm{~h}$, the cells on the upper side of the filters were removed mechanically, while cells that migrated to the bottom side were fixed in $4 \%(\mathrm{w} / \mathrm{v})$ paraformaldehyde. The migrated cells were photographed and counted using Image-Pro Plus. Three independent experiments were performed.

For the invasion assay, modified polycarbonate Transwell filters (Corning Costar) coated with Matrigel (Matrigel basement membrane matrix; BD Biosciences) were used. The upper surface of the filter was coated with $60 \mu \mathrm{l}$ Matrigel $(4 \mathrm{mg} / \mathrm{ml})$ at $37^{\circ} \mathrm{C}$ for $30 \mathrm{~min}$. Cells were suspended in culture medium containing various concentrations of $\mathrm{rH}(25,50$ or $100 \mu / \mathrm{ml})$ or DOX $(4 \mu \mathrm{g} / \mathrm{ml})$ and added to the upper chamber. The bottom chambers were filled with culture medium containing bFGF ( $3 \mathrm{ng} / \mathrm{ml}$ ). After incubation for $16 \mathrm{~h}$, cells on the upper surface of the filter were removed by scraping, and the invaded cells on the bottom side were fixed in $4 \%(\mathrm{w} / \mathrm{v})$ paraformaldehyde. The invaded cells were photographed and counted using Image-Pro Plus software. Three independent experiments were performed.

Cell apoptosis assay. For detection of cell apoptosis, the Hep-2 cells were stained with Hoechst 33324 (Beyotime). In brief, cells were plated on coverslips and treated with various concentrations of $\mathrm{rH}(0.5,1$ or $2 \mathrm{mg} / \mathrm{ml})$ or DOX $(4 \mu \mathrm{g} / \mathrm{ml})$ for $24 \mathrm{~h}$, followed by washing in PBS (pH 7.4) and fixing with $4 \%(\mathrm{w} / \mathrm{v})$ paraformaldehyde at room temperature for $10 \mathrm{~min}$. Following fixation, cells were washed three times in PBS (pH 7.4) and stained with Hoechst 33324 according to the manufacturer's instructions. Stained nuclei were observed and photographed under a fluorescence microscope. Cells undergoing apoptosis demonstrated blue fluorescent nuclei (intact or fragmented). Three independent experiments were performed.

Chick chorioallantoic membrane assay. The chicken chorioallantoic membrane (CAM) assay is an established in vivo model for investigating the process of new blood vessel formation and vessel responses to anti-angiogenic agents (13). We thereby applied the CAM assay to assess the effect of $\mathrm{rH}$ on angiogenesis. All experiments were performed on day 6 of chick embryo development, when CAM and its vasculature are well-developed. A $1 \mathrm{~cm}^{2}$ window was made in the shell under aseptic conditions. Next, a sterile methylcellulose disc was added with $20 \mu \mathrm{l}$ of recombinant human bFGF (10 ng/ $\mu \mathrm{l})$ (Roche) or vehicle PBS and placed on the CAM. The window 
A

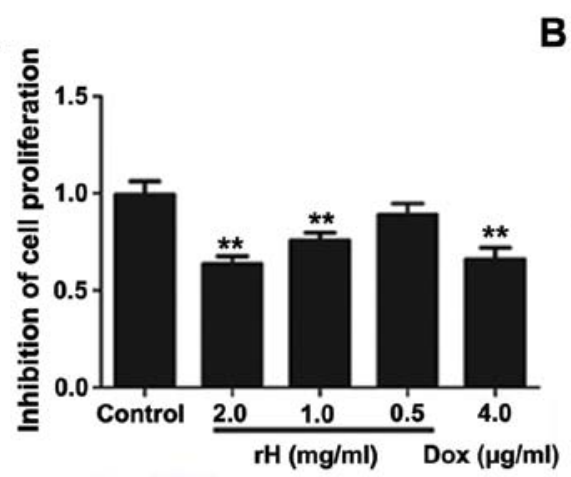

G
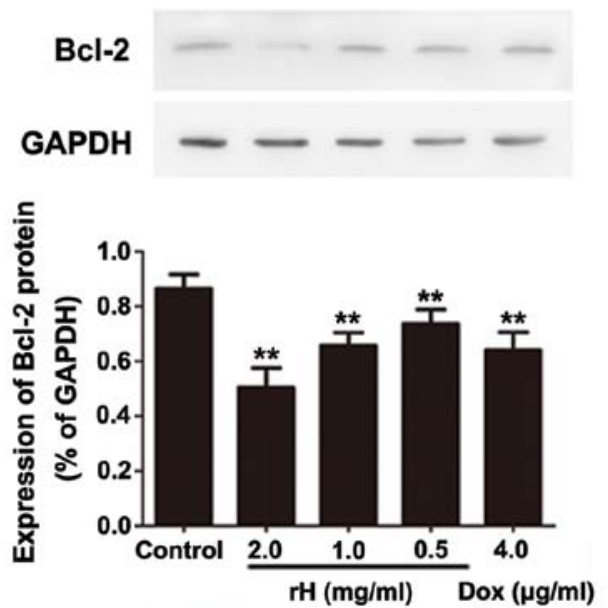
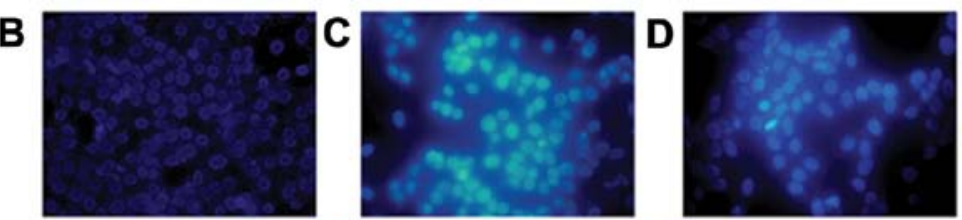

E

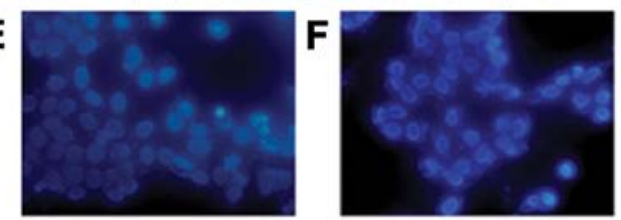

H
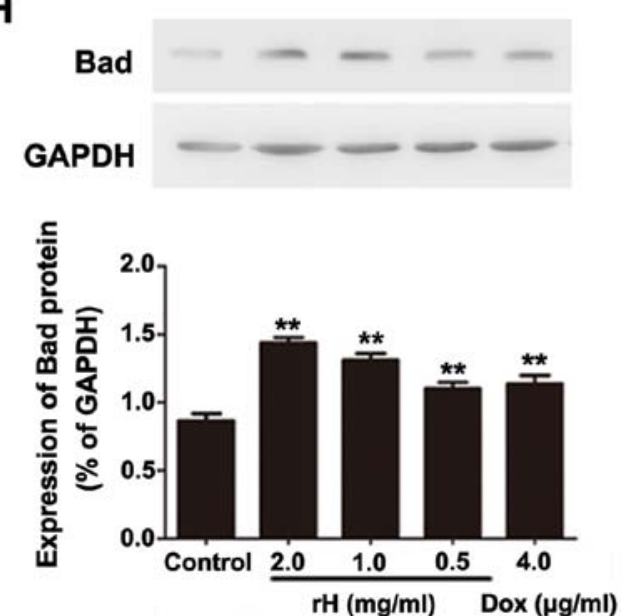

Figure 1. rH inhibits cell viability and induces apoptosis of Hep-2 cells. (A) WST assay was applied to evaluate the cell viability of Hep-2 cells following treatment with the indicated drugs for $24 \mathrm{~h}$. (B-E) Morphological analysis of nuclear chromatin by staining with Hoechst 33324 . Fragmented nuclei stained with Hoechst 33324 indicate apoptotic cells. Representative images (magnification, $\mathrm{x} 400$ ) show stained cells treated with (B) PBS, (C) 2 mg/ml $\mathrm{rH}$, (D) $1 \mathrm{mg} / \mathrm{ml}$ $\mathrm{rH}$, (E) $0.5 \mathrm{mg} / \mathrm{ml} \mathrm{rH}$ or $(\mathrm{F}) 4 \mu \mathrm{g} / \mathrm{ml}$ DOX. (G and H) Hep-2 cells were treated with the indicated drugs for $24 \mathrm{~h}$. Whole-cell protein lysates $(60 \mu \mathrm{g} / \mathrm{lane})$ were subjected to western blot analysis for $(\mathrm{G}) \mathrm{Bcl}-2$ and $(\mathrm{H})$ Bad proteins. Band intensity was quantified using the Gel-Pro Analyser 4.0 software. Data are presented as the means \pm SD of at least three independent experiments. ${ }^{* *}$ p $<0.01$, compared with the negative control. rH, recombinant hirudin; WST, watersoluble tetrazolium salt; DOX, doxorubicin hydrochloride.

was sealed with sterile scotch tape and the egg was kept in an incubator at $37^{\circ} \mathrm{C}$ with $60 \%$ humidity for $24 \mathrm{~h}$. Then, various concentrations of $\mathrm{rH}(0.5,1$ or $2 \mathrm{mg} / \mathrm{ml})$ or PBS was pipetted onto the methylcellulose disc and the window was sealed again with sterile scotch tape. The egg was incubated for an additional $24 \mathrm{~h}$, observed and photographed with a Nikon digital camera.

Western blot analysis. After the $\mathrm{rH}$ treatment, Hep-2 cells were washed with ice-cold PBS ( $\mathrm{pH} 7.4)$ and scraped into lysis buffer (KeyGen Biotech, Nanjing, China). The lysate was collected by centrifugation at $12,000 \mathrm{x}$ g for $15 \mathrm{~min}$ at $4^{\circ} \mathrm{C}$, and the supernatant (total cell lysate) was stored at $-80^{\circ} \mathrm{C}$. Protein concentrations were determined with a BCA protein assay reagent (Beyotime). Proteins $(60 \mu \mathrm{g})$ were separated using SDS-PAGE and transferred to a PVDF membrane. Membranes were blocked with Tris-buffered saline (TBS; $137 \mathrm{mM} \mathrm{NaCl}$, $20 \mathrm{mM}$ Tris- $\mathrm{HCl}, \mathrm{pH} 7.5$ ) containing $0.1 \%$ Tween-20 and 5\% dried milk powder. Rabbit anti-mouse VEGF-R antibody (diluted 1:1,000), rabbit anti-mouse FAK antibody (diluted 1:1,000) (both from Santa Cruz Biotechnology, Santa Cruz, CA, USA), rabbit anti-mouse Bcl-2 antibody (diluted 1:1,000; Bioworld Technology, USA) and rabbit anti-mouse Bad anti- body (diluted 1:1,000; Proteintech Group, Chicago, IL, USA) were used to detect the corresponding proteins. Signals were developed with the enhanced chemiluminescence detection system (Beyotime). Relative intensities of the specific bands were quantified using Gel-Pro Analyser 4.0 software.

Statistical analysis. Statistical analysis was performed on SPSS version 16.0 (version 16.1; SPSS, Inc., Chicago, IL, USA). All values are expressed as means \pm standard deviation (SD) of at least three independent experiments. p-values were determined by the Student's t-test and one-way ANOVA, with $\mathrm{p}<0.05$ considered to indicate a statistically significant result.

\section{Results}

Treatment of Hep-2 cells with rH results in loss of cell viability and apoptosis. To investigate the effects of $\mathrm{rH}$ on the cell viability of human laryngeal cancer cells, Hep-2 cells were treated with varying concentrations of $\mathrm{rH}(0.5,1$ or $2 \mathrm{mg} / \mathrm{ml})$ in parallel with a standard widely used clinical chemotherapy drug (DOX) for $24 \mathrm{~h}$, and subjected to a WST assay. As shown in Fig. 1A, compared to the negative control group, treatment of cells with $\mathrm{rH}$ resulted in a significant reduction in cell 


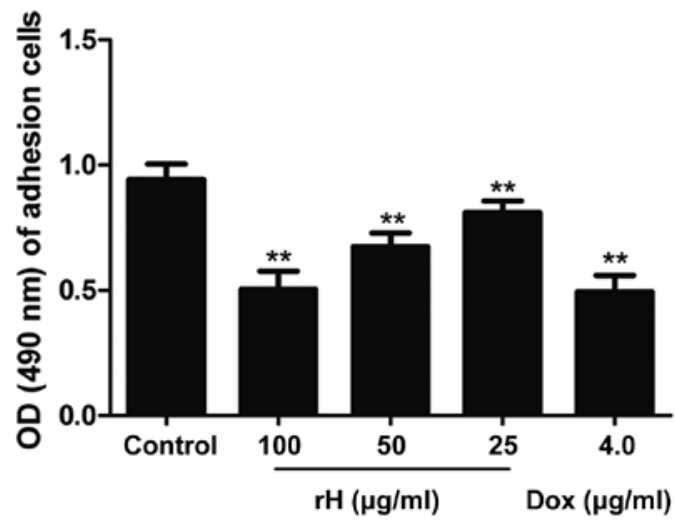

Figure 2. rH inhibits the adhesive ability of Hep-2 cells. Hep-2 cells were seeded into fibronectin-coated 96-well plates and treated with the indicated drugs for $24 \mathrm{~h}$. The number of attached cells was determined to reflect their adhesive ability. Data are presented as the means \pm SD of at least three independent experiments. ${ }^{* *} \mathrm{p}<0.01$, compared with the negative control. $\mathrm{rH}$, recombinant hirudin.

A

B

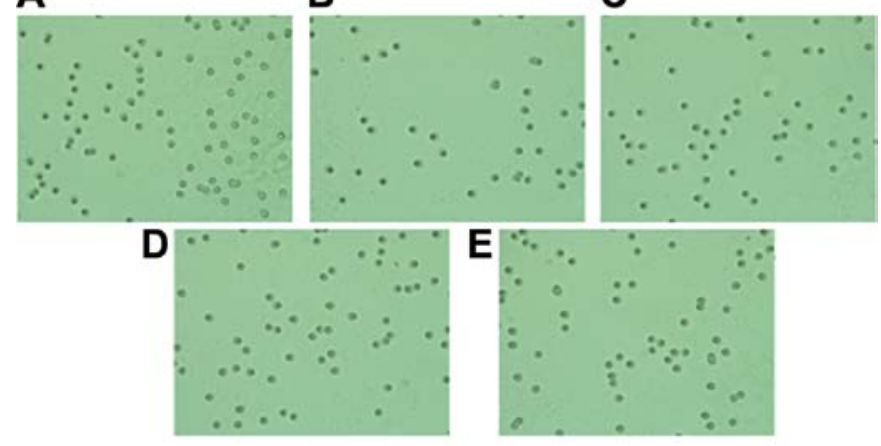

$\mathbf{F}$

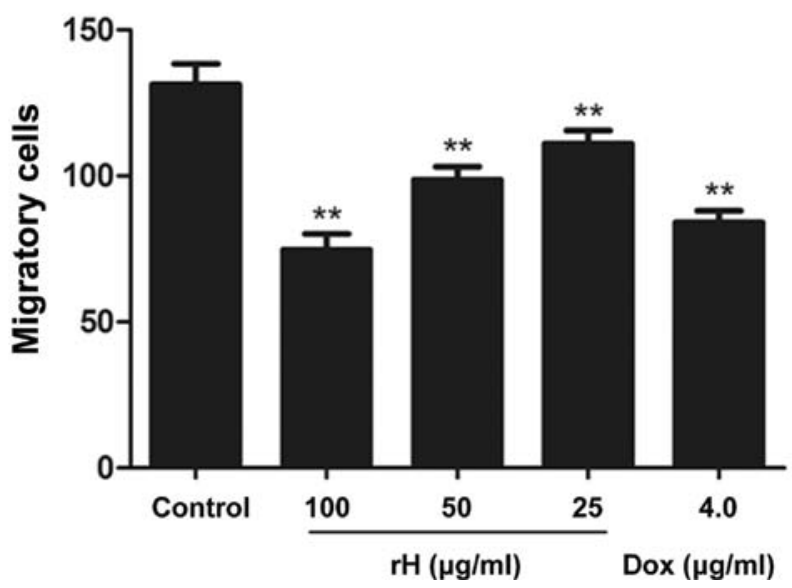

Figure 3. $\mathrm{rH}$ inhibits the migration of Hep-2 cells. Hep-2 cells were loaded into the upper wells of the chamber and treated with the indicated drugs for $24 \mathrm{~h}$. Cells that migrated to the lower side of the polycarbonate membrane were photographed and counted. Representative images show migrated cells following treatment with (A) PBS, (B) $100 \mu \mathrm{g} / \mathrm{ml} \mathrm{rH}$, (C) $50 \mu \mathrm{g} / \mathrm{ml} \mathrm{rH}$, (D) $25 \mu \mathrm{g} / \mathrm{ml} \mathrm{rH}$ or (E) $4 \mu \mathrm{g} / \mathrm{ml}$ DOX. (F) Quantification of migrated cells is shown. Data are presented as the means \pm SD of at least three independent experiments. ${ }^{* *} \mathrm{p}<0.01$, compared with the negative control. $\mathrm{rH}$, recombinant hirudin.

viability in a dose-dependent manner. The inhibitory rate increased from 12.7 to $39.8 \%$ at $24 \mathrm{~h}$ as the concentration of $\mathrm{rH}$ was escalated from 0.5 to $2 \mathrm{mg} / \mathrm{ml}$. The inhibitory effect of

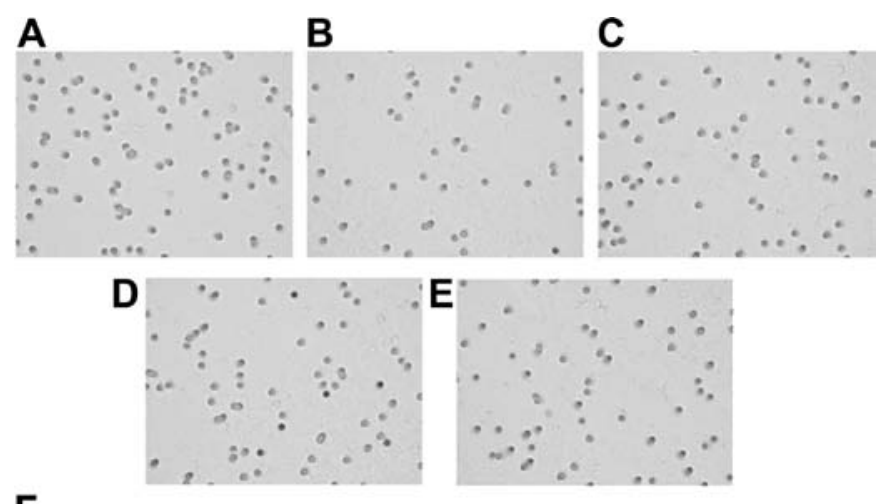

$\mathbf{F}$

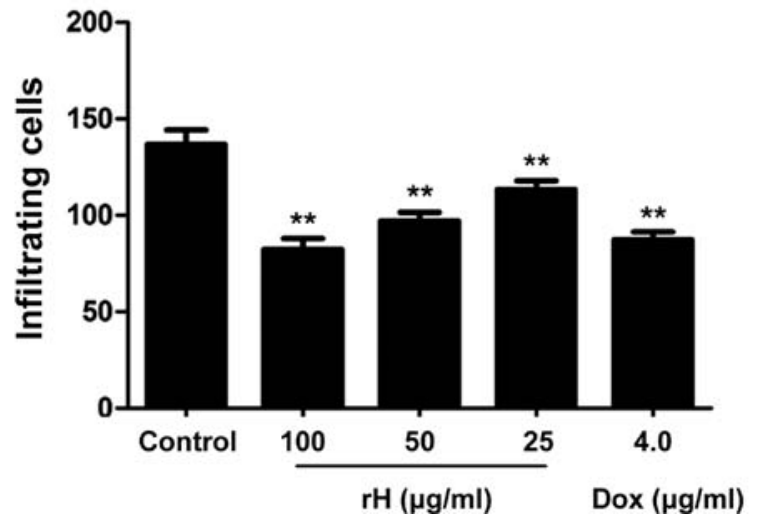

Figure 4. rH inhibits the matrix invasion of Hep-2 cells. The model used in this experiment was the same as that used in the migration assay. The difference was that the membrane used in this experiment was coated with ECM Matrigel. Cells that invaded to the lower side of the polycarbonate membrane were photographed and counted. Representative images show the invasive cells treated with (A) PBS, (B) $100 \mu \mathrm{g} / \mathrm{ml} \mathrm{rH}$, (C) $50 \mu \mathrm{g} / \mathrm{ml} \mathrm{rH}$, (D) $25 \mu \mathrm{g} / \mathrm{ml}$ $\mathrm{rH}$ or (E) $4 \mu \mathrm{g} / \mathrm{ml}$ DOX. (F) Quantification of invasive cells is shown. Data are presented as the means \pm SD of at least three independent experiments. ${ }^{* *} \mathrm{p}<0.01$, compared with the negative control. $\mathrm{rH}$, recombinant hirudin.

$\mathrm{rH}$ at $2 \mathrm{mg} / \mathrm{ml}$ was similar to that of DOX at a concentration of $4 \mu \mathrm{g} / \mathrm{ml}$. Thus, $\mathrm{rH}$ inhibits the cell viability of Hep-2 human laryngeal cancer cells.

To ascertain the mechanism of the loss of cell viability following $\mathrm{rH}$ treatment, we detected the effect of $\mathrm{rH}$ on the apoptosis of Hep- 2 cells. We first used Hoechst 33324 staining to observe the change of morphology after $\mathrm{rH}$ treatment. As shown in Fig. 1B-F, cells exposed to $\mathrm{rH}$ for $24 \mathrm{~h}$ showed apparent cell shrinkage, chromatin compaction and nuclear fragmentation, all of which are typical apoptotic morphological changes. Similar morphological alterations were observed in the Hep-2 cells treated with DOX (Fig. 1F). In contrast, no obvious apoptosis was observed in the negative control cells. These results indicated that induction of cell apoptosis is one of the mechanisms by which $\mathrm{rH}$ inhibits the proliferation of Hep- 2 cells.

To further support the above conclusion, we treated Hep- 2 cells with $\mathrm{rH}$ and DOX, and determined the expression of the apoptosis-associated proteins Bad and Bcl-2 by western blot analysis. One of the cytotoxic effects of DOX is the induction of apoptosis (14). As expected, DOX decreased the anti-apoptotic protein Bcl-2 (Fig. 1G), while it increased the pro-apoptotic protein Bad (Fig. 1H). Similarly, $\mathrm{rH}$ dose-dependently decreased Bcl-2 (Fig. 1G), yet increased Bad (Fig. 1H). These data suggest that $\mathrm{rH}$ inhibits cell 


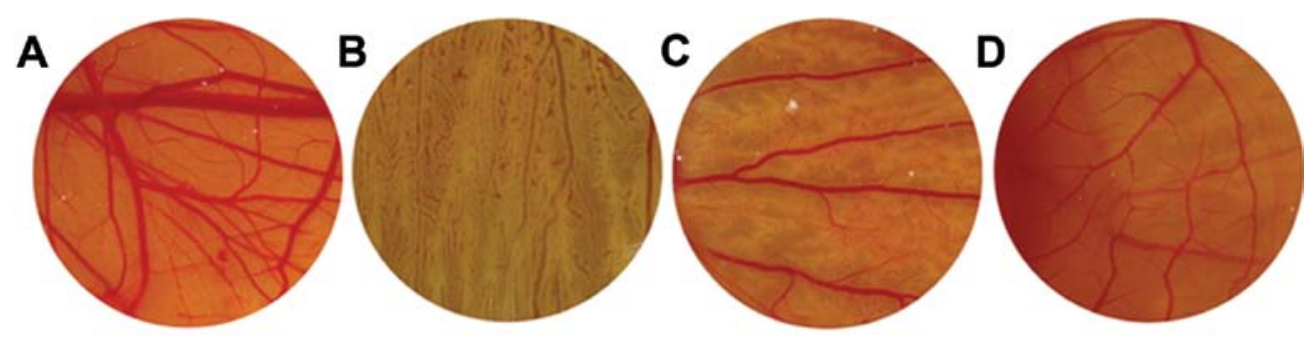

E
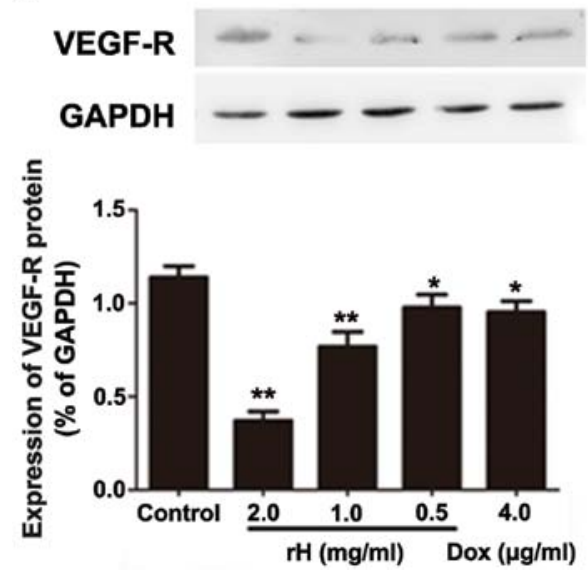

$\mathbf{F}$
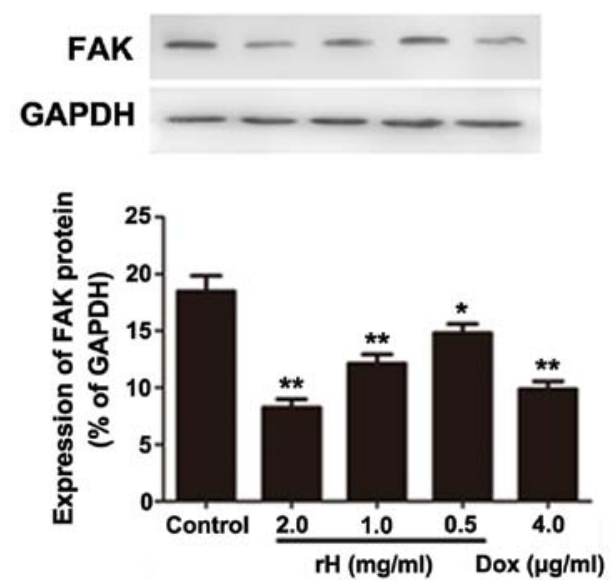

Figure 5. rH inhibits angiogenesis in vivo and suppresses the protein levels of VEGF-R and FAK in the Hep-2 cells. Methylcellulose discs containing (A) PBS, (B) $2 \mathrm{mg} / \mathrm{ml} \mathrm{rH}$, (C) $1 \mathrm{mg} / \mathrm{ml} \mathrm{rH}$ or (D) $0.5 \mathrm{mg} / \mathrm{ml} \mathrm{rH}$ were implanted on CAMs of 7 day old chick embryos induced by bFGF for 24 h. The inhibitory effect of $\mathrm{rH}$ on bFGF (200 ng/disc) induced CAM angiogenesis was observed and photographed with a Nikon digital camera. (E and F) Hep-2 cells were treated with the indicated drugs for $24 \mathrm{~h}$. Whole-cell protein lysates $(60 \mu \mathrm{g} / \mathrm{lane})$ were subjected to western blot analysis for (E) VEGF-R and (F) FAK proteins. Band intensity was quantified using Gel-Pro Analyser 4.0 software. Data are presented as the means \pm SD of at least three independent experiments. ${ }^{*}<0.05$, ${ }^{* *} \mathrm{p}<0.01$, compared with the negative control. $\mathrm{rH}$, recombinant hirudin.

viability and induces apoptosis in Hep-2 cells, at least partly, by regulating the levels of pro-apoptotic and anti-apoptotic proteins.

$r H$ inhibits the adhesion, migration and matrix invasion of Hep-2 cells. The adhesion of cancer cells to the extracellular matrix and cell surface molecules is a key step during metastasis in vivo (15). We next aimed to ascertain whether $\mathrm{rH}$ promotes the adhesion of Hep- 2 cells to the extracellular matrix and cell surface molecules by testing the adhesion of Hep-2 cells to fibronectin. $\mathrm{rH}(50-100 \mu \mathrm{g} / \mathrm{ml})$ significantly inhibited the adhesion of Hep-2 cells to fibronectin, while $25 \mu \mathrm{g} / \mathrm{ml}$ did not (Fig. 2). The reduction in cell adhesion capabilities following $\mathrm{rH}$ treatment at concentrations of 25 to $100 \mu \mathrm{g} / \mathrm{ml}$ was increased from 13.4 to $46.5 \%$. The inhibitory effect of $\mathrm{rH}$ at $100 \mu \mathrm{g} / \mathrm{ml}$ was approximately equal to that of DOX at $4 \mu \mathrm{g} / \mathrm{ml}$.

We further assessed the in vitro migration and invasion of Hep-2 cells following treatment with $\mathrm{rH}$ using the Boyden chamber model. Results from the migration assay showed that the number of cells that migrated to the lower side of the membrane was significantly reduced in the $\mathrm{rH}$-treated groups in a dose-dependent manner, as compared to the untreated cells (Fig. 3A-D). Treatment of the cells with 25, 50 or $100 \mu \mathrm{g} / \mathrm{ml} \mathrm{rH}$ for $24 \mathrm{~h}$ inhibited cell migration by $15.5,24.9$ and $43.1 \%$, respectively (Fig. $3 F$ ). Treatment of Hep-2 cells with $4 \mu \mathrm{g} / \mathrm{ml}$ of DOX led to a $36.0 \%$ reduction in cell migration (Fig. 3E and F).
Movement of cells through Matrigel-coated Boyden chambers mimics the early steps of tumor invasion (16). We thus applied a Matrigel assay to test whether $\mathrm{rH}$ affects the invasion of Hep-2 cells and found that $\mathrm{rH}$ significantly decreased bFGFinduced cell invasion through the Matrigel in a dose-dependent manner (Fig. 4A-D and F). Relative to the untreated control, treatment of Hep-2 cells with 25,50 or $100 \mu \mathrm{g} / \mathrm{ml} \mathrm{rH}$ for $24 \mathrm{~h}$ inhibited the number of cells invading the lower chamber by 17.1, 29.0 and $39.8 \%$, respectively. The inhibitory effect of $100 \mu \mathrm{g} / \mathrm{ml}$ of $\mathrm{rH}$ was approximately equal to that of $4 \mu \mathrm{g} / \mathrm{ml}$ DOX (Fig. 4E and F). These results demonstrated that $\mathrm{rH}$ significantly decreased the migratory and invasive capabilities of the Hep-2 cells.

rH inhibits angiogenesis in vivo. Rapidly proliferating tumor cells rely on sustained angiogenesis, a hallmark of cancer cells (17). To determine whether $\mathrm{rH}$ suppresses microvessel formation in vivo, we performed a CAM assay using day 6 fertilized eggs. PBS-treated CAMs showed normal vascularization with primary, secondary and tertiary vessels and dendritic branching (Fig. 5A). In sharp contrast, rH-disc implanted CAMs demonstrated significantly reduced formation of new microvessels in a dose-dependent manner (Fig. 5B-D). rH significantly decreased the vessel area, vessel length and number of dendrites. Impressively, the addition of $\mathrm{rH}$ at $2 \mathrm{mg} / \mathrm{ml}$ totally blocked the microvessel formation (Fig. 5B-D). These results indicate that $\mathrm{rH}$ possesses the capacity for anti-angiogenesis. 
$r H$ suppresses the protein levels of VEGF-R and FAK. VEGF and its corresponding receptor (VEGF-R) are important regulators of tumor angiogenesis. Moreover, VEGF-Rs are not only expressed on endothelia, yet also on different types of solid tumor cells and leukemic cells (18-20). FAK is a cytoplasmic tyrosine kinase that plays a fundamental role in integrin and growth factor-mediated signaling, and plays critical roles in cell migration and proliferation, processes vital for angiogenesis (21). The increased expression of FAK in cancer cells has been suggested to play a role in the tumor angiogenic switch to promote aggressive tumor progression and metastasis (22). To assess the mechanism of the inhibition of angiogenesis and explore the possible molecules involved in $\mathrm{rH}$-induced reduction of migration and invasion in Hep- 2 cells, we determined the expression of VEGF-R and FAK by western blot analysis. Compared to PBS, DOX apparently reduced the protein levels of VEGF-R and FAK. Exposure of Hep-2 cells to $\mathrm{rH}$ for $24 \mathrm{~h}$ resulted in decreased expression levels of VEGF-R and FAK in a dose-dependent manner (Fig. 5E and F), suggesting that $\mathrm{rH}$ reduces adhesion, migration, invasion and angiogenesis of cancer cells through suppressing VEGF-R and FAK expression.

\section{Discussion}

In the present study, we found that $\mathrm{rH}$ dose-dependently suppressed the viability, adhesion, migration and invasion of Hep-2 human laryngeal carcinoma (LC) cells. Treatment of Hep-2 cells with $\mathrm{rH}$ resulted in reduced cell viability accompanied by increased expression of Bad and decreased expression of Bcl-2. In addition, we discovered that $\mathrm{rH}$ inhibited angiogenesis and decreased the expression of VEGF-R and FAK.

Thrombin promotes tumor cell growth, angiogenesis and metastasis by stimulating the adhesion of tumor cells to platelets and endothelium (23). These functions of thrombin mainly depend on the cell surface receptor of thrombin, the protease-activated receptor (PAR). Binding of thrombin to PAR-1 results in activation of PAR-1, which in turn induces a series of physiological reactions and hence promotes the growth of tumor cells in vivo $(23,24) . \mathrm{rH}$ is a highly specific and potent inhibitor of thrombin and has shown inhibitory effects against tumor growth and metastasis in experimental tumor models. In the present study, we evaluated the antitumor effects of $\mathrm{rH}$ in human laryngeal cancer with Hep-2 cells, which express PAR-1 on their cell surface (25). Our results demonstrated that $\mathrm{rH}$ inhibited cell viability, adhesion, migration and invasion, and induced apoptosis in Hep- 2 cells, suggesting that $\mathrm{rH}$ is a potential therapeutic agent for LC.

Apoptosis is a tightly regulated process that involves at least one of the caspase-dependent signaling pathways, i.e., the cell death receptor pathway or the mitochondrial pathway (26). Among the numerous factors known to modulate apoptosis in cancer cells, the proteins of the $\mathrm{Bcl}-2$ family are considered to be the main regulators. Bcl-2 is an anti-apoptotic protein (26), whereas $\mathrm{Bad}$ is a crucial pro-apoptotic and tumor-suppressor protein (27). The ability to induce cellular apoptosis is an important property of many anticancer drugs (28). Our results showed that $\mathrm{rH}$ suppressed cell viability and induced apoptosis in Hep-2 cells in a dose-dependent manner. Similarly, $\mathrm{rH}$ not only downregulated Bcl-2, yet also upregulated Bad in Hep-2 cells in a dose-dependent manner compared to PBS. These results indicate that $\mathrm{rH}$ induces apoptosis of cancer cells via regulating the expression of key regulators in the apoptosis process.

Sustained angiogenesis, and enhanced invasion and metastasis, are two hallmarks of cancer cells (29). LC is a type of solid tumor with a high potential for metastasis and invasion (15). It is now widely accepted that most patients with solid tumors die from metastasis, yet not the growth of the primary tumors (15). Thus, targeting angiogenesis and metastasis is one of the most rational and promising strategies for the development of anticancer drugs. We observed that $\mathrm{rH}$ inhibited the adhesion, migration and invasion of cultured Hep-2 cells, and suppressed angiogenesis in a CAM model. At the molecular level, the expression levels of VEGF-R and FAK were inhibited by $\mathrm{rH}$ in a dose-dependent manner. A previous study indicated that FAK plays a pivotal role in cancer cell survival, migration, invasion and angiogenesis (30). The VEGF/VEGF-R pathway not only regulates neoangiogenesis, yet also influences the matrix-related migratory activity by interaction with focal adhesion kinase (p125FAK) and prolinerich tyrosine kinase $\beta$ (PYK2/CAK $\beta$ ) (31). Therefore, $r H$ suppresses the adhesion, migration and invasion of Hep-2 cells partly by reducing the expression of VEGF-R and FAK.

A previous study suggested that $\mathrm{rH}$ had no impact on adhesion to extracellular matrix (ECM) proteins, migration and invasion of in vitro cultured human A375 melanoma cells (10). However, our data clearly showed that $\mathrm{rH}$ inhibited Hep-2 cell adhesion to fibronectin, migration and invasion in a dose-dependent manner. Such discrepancies may result from differences in cell models or other experimental methods. For example, in a study by Guo et al, melanoma cells were treated with $\mathrm{rH}$ for only $30 \mathrm{~min}$ (10), while Hep-2 cells were treated with $\mathrm{rH}$ for $24 \mathrm{~h}$ during the migration and invasion assays in our experiments.

In conclusion, $\mathrm{rH}$ inhibited cell viability, adhesion, migration and invasion, and induced apoptosis in Hep-2 cells. The underlying mechanisms may be associated with the regulation of the expression of key regulators involved in these processes, such as VEGF-R, FAK, Bcl-2 and Bad. Our data may accelerate the development of $\mathrm{rH}$ as a novel therapeutic agent for the treatment of cancers with a deregulated thrombin/PAR-1 signaling pathway, including LC.

\section{Acknowledgements}

This study was supported by the Science and Technology Plan Projects of Dalian (no. 2010E15SF180). We would like to thank Professor Li Lv and Professor Jihong Yao, and the students of Feng Yu, Xiaohan Zhai and Hu Yan, Department of Pharmacology, Dalian Medical University, for their technical assistance.

\section{References}

1. Marioni G, Marchese-Ragona R, Cartei G, Marchese F and Staffieri A: Current opinion in diagnosis and treatment of laryngeal carcinoma. Cancer Treat Rev 32: 504-515, 2006.

2. Papadas TA, Alexopoulos EC, Mallis A, Jelastopulu E, Mastronikolis NS and Goumas P: Survival after laryngectomy: a review of 133 patients with laryngeal carcinoma. Eur Arch Otorhinolaryngol 267: 1095-1101, 2010. 
3. Moubayed SP, Bélair M, Saliba J, et al: Prognostic value of cartilage sclerosis in laryngeal cancer treated with primary radiation therapy. Otolaryngol Head Neck Surg 147: 57-62, 2012.

4. Taki S, Homma A, Suzuki F, et al: Combined modality therapy for laryngeal cancer with superselective intra-arterial cisplatin infusion and concomitant radiotherapy. Int J Clin Oncol 17: 441-446, 2012

5. Agra IM, Ferlito A, Takes RP, et al: Diagnosis and treatment of recurrent laryngeal cancer following initial nonsurgical therapy. Head Neck 34: 727-735, 2012.

6. Chai LP, Wang ZF, Liang WY, et al: In vitro and in vivo effect of 5 -FC combined gene therapy with TNF- $\alpha$ and $C D$ suicide gene on human laryngeal carcinoma cell line Hep-2. PLoS One 8: e61136, 2013.

7. Trzcieniecka-Green A, Bargiel-Matusiewicz K and Borczyk J: Quality of life of patients after laryngectomy. J Physiol Pharmacol 58 (Suppl 5): S699-S704, 2007.

8. Yoda Y and Abe T: Fibrinopeptide A (FPA) level and fibrinogen kinetics in patients with malignant disease. Thromb Haemost 46 706-709, 1981

9. Green D and Karpatkin S: Role of thrombin as a tumor growth factor. Cell Cycle 9: 656-661, 2010.

10. Guo RR, Liu Y, Lu WL, et al: A recombinant peptide, hirudin, potentiates the inhibitory effects of stealthy liposomal vinblastine on the growth and metastasis of melanoma. Biol Pharm Bull 31: 696-702, 2008

11. Hu L, Lee M, Campbell W, Perez-Soler R and Karpatkin S: Role of endogenous thrombin in tumor implantation, seeding, and spontaneous metastasis. Blood 104: 2746-2751, 2004.

12. Caunt M, Huang YQ, Brooks PC and Karpatkin S: Thrombin induces neoangiogenesis in the chick chorioallantoic membrane. J Thromb Haemost 1: 2097-2102, 2003.

13. Liu M, Scanlon CS, Banerjee R, et al: The histone methyltransferase EZH2 mediates tumor progression on the chick chorioallantoic membrane assay, a novel model of head and neck squamous cell carcinoma. Transl Oncol 6: 273-281, 2013.

14. Mackler NJ and Pienta KJ: Drug insight: Use of docetaxel in prostate and urothelial cancers. Nat Clin Pract Urol 2: 92-100, 2005.

15. Zhang H, Yang D, Wang H, et al: Metastasis-associated gene 1 promotes invasion and migration potential of laryngeal squamous cell carcinoma cells. Oncol Lett 7: 399-404, 2014.

16. Ren J, Zhu D, Liu M, Sun Y and Tian L: Downregulation of miR-21 modulates Ras expression to promote apoptosis and suppress invasion of Laryngeal squamous cell carcinoma. Eur J Cancer 46: 3409-3416, 2010.

17. Folkman J: Angiogenesis in cancer, vascular, rheumatoid and other disease. Nat Med 1: 27-31, 1995

18. Guo S, Colbert LS, Fuller M, Zhang Y and Gonzalez-Perez RR Vascular endothelial growth factor receptor-2 in breast cancer. Biochim Biophys Acta 1806: 108-121, 2010.
19. Dias S, Choy M, Alitalo K and Rafii S: Vascular endothelial growth factor (VEGF)-C signaling through FLT-4 (VEGFR-3) mediates leukemic cell proliferation, survival, and resistance to chemotherapy. Blood 99: 2179-2184, 2002.

20. Dias S, Hattori K, Zhu Z, et al: Autocrine stimulation of VEGFR-2 activates human leukemic cell growth and migration. J Clin Invest 106: 511-521, 2000.

21. Tavora B, Batista S, Reynolds LE, et al: Endothelial FAK is required for tumour angiogenesis. EMBO Mol Med 2: 516-528, 2010.

22. Gabarra-Niecko V, Schaller MD and Dunty JM: FAK regulates biological processes important for the pathogenesis of cancer. Cancer Metastasis Rev 22: 359-374, 2003.

23. Even-Ram S, Uziely B, Cohen P, et al: Thrombin receptor overexpression in malignant and physiological invasion processes. Nat Med 4: 909-914, 1998.

24. Shi X, Gangadharan B, Brass LF, Ruf W and Mueller BM: Protease-activated receptors (PAR1 and PAR2) contribute to tumor cell motility and metastasis. Mol Cancer Res 2: 395-402, 2004.

25. Kaufmann R, Schafberg H, Rudroff C and Nowak G: Thrombin receptor activation results in calcium signaling and protein kinase C-dependent stimulation of DNA synthesis in HEp-2g laryngeal carcinoma cells. Cancer 80: 2068-2074, 1997.

26. Zhang S, Yang Y, Liang Z, et al: Silybin-mediated inhibition of Notch signaling exerts antitumor activity in human hepatocellular carcinoma cells. PLoS One 8: e83699, 2013.

27. Jaganathan R, Ravinayagam V, Panchanadham S and Palanivelu S: Potential therapeutic role of Tridham in human hepatocellular carcinoma cell line through induction of p53 independent apoptosis. BMC Complement Altern Med 13: 323, 2013.

28. Nguyen KC, Willmore WG and Tayabali AF: Cadmium telluride quantum dots cause oxidative stress leading to extrinsic and intrinsic apoptosis in hepatocellular carcinoma HepG2 cells. Toxicology 306: 114-123, 2013.

29. Hanahan D and Weinberg RA: Hallmarks of cancer: the next generation. Cell 144: 646-674, 2011.

30. Thanapprapasr D, Hu W, Sood AK and Coleman RL: Moving beyond VEGF for anti-angiogenesis strategies in gynecologic cancer. Curr Pharm Des 18: 2713-2719, 2012.

31. Ludwig HC, Akhavan-Shigari R, Rausch S, et al: Expression of focal adhesion kinase (p125 FAK) and proline-rich tyrosine kinase 2 (PYK2/CAKb) in cerebral metastases, correlation with VEGF-R-, ecNOS III-labelling and morphometric data. Anticancer Res 20: 1419-1424, 2000. 